European Journal of Accounting, Auditing and Finance Research

Vol.8, No.3, pp.59-68, March 2020

Published by ECRTD-UK

Print ISSN: 2053-4086(Print), Online ISSN: 2053-4094(Online)

\title{
Causal Relationship between Financial Structure and Economic Growth in Contemporary African Economy: A Case Study of Nigeria from 1990-2018
}

\author{
Henry Yua ${ }^{1}$ \\ Banking and Finance Department, Nigerian Army College of Environmental Studies and \\ Technology \& Doctoral Student of Banking and Finance Department, Nnamdi Azikiwe \\ University, Awka Anambra state
}

Francis Uju Adoms ${ }^{2}$

Addyfx Nig. Ltd \& Doctoral Student of Banking and Finance Department, Nnamdi Azikiwe University, Awka Anambra state

\author{
, Celestine S. Okaro (Ph.D) ${ }^{\mathbf{3}}$ \&, Kelechukwu Stanley Ogbonna (Ph.D) ${ }^{4}$ \\ Banking and Finance Department, Nnamdi Azikiwe University, Awka Anambra state

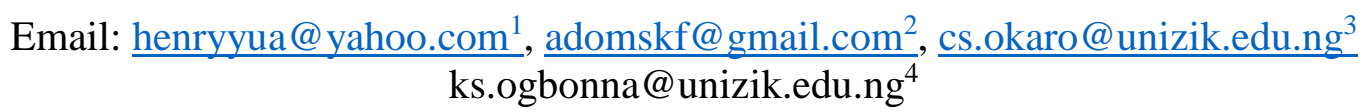

\begin{abstract}
This study examined financial structure and economic growth of contemporary African economies; evidence from Nigeria. The specific objectives of this study are to investigate the effect of financial structure in bank credit to the private sector ratio $(B C)$, market capitalization ratio (MC), liquid liability ratio (LLR), turnover ratio $(T R)$ and value of traded share (VTS) on economic growth variable in Gross Domestic Product (GDP). The study was anchored on bank based and market-based theory. The study used secondary data obtained from World Bank Data Atlas and subjected them to Granger Causality technique to test the interaction between independent variables and the dependent variable at the 5\% level of significance. The findings show that financial structure in BC, MC, LLR, TR and VTS had no significant effect on GDP in the contemporary African economies. The result further discovered that there was absence of long run relationship in the study. Thus, the study concludes that financial structure does not have significant effect on economic growth in the contemporary African economies. Hence, the study recommends that financial structure should strengthen and enhance availability of money supply to key sector of the economy thereby improving economic growth by ensuring financial deepening within the economies and providing viable economic environment for financial enhancement to boost investment activities within the Nigerian economy.
\end{abstract}

KEYWORDS: financial structure, bank credit, market capitalization, economic growth, GDP

\section{INTRODUCTION}

Financial structure (FS) of economies comes in different sizes and shapes. The significance of FS, whether by banks or stock markets to economic growth of a country is central to its economic policy decision (Oima \& Ojwang 2013). The primary policy question confronting governments is which FS is optimal given each country's economic growth's level and circumstances (Rateiwa \& Aziakpono 2016 and Demirgüç-Kunt, Feyen \& Levine, 2011, 2012). 
Print ISSN: 2053-4086(Print), Online ISSN: 2053-4094(Online)

The forgoing further left policy makers with a number of questions: how to make credit flow to where it's needed most for maximum impact; how to design and regulate banks and microfinance institutions; how to grow their stock exchange in a manner that supports economic growth; what is the appropriate structure of financial systems that will optimally stimulate economic growth; and how to obtain financing for long-term and riskier projects.

Financial structure is broadly defined as the mix of financial instruments, financial markets, and financial institutions in a country (Naomi \& Eftychia, 2018). Financial structure with more reliance on the banking system is characterised as bank-based, while one that relies more on the 'stock market' is characterised as market-based (Guei, 2018). More formally, financial 'structure is defined as the degree to which a country has a bank-based or market-based FS' (Ndako, 2017; Demirguc-Kunt \& Levine, 2001). Market-based financial systems decrease the integral inadequacies connected with financial institutions and however, healthier at improving economic development. Bank-based financial systems further ease alterations stemming from lop-sided evidence via establishing long-run understanding with firms, and monitoring to contain moral hazard (Ibadan, Moni, \& Eikhomun, 2014).

Financial structure performs the function of mobilizing savings, allocating capital, providing an efficient payment system, monitoring and exerting corporate governance and ameliorating risk and the creation of money in the economy to enable businesses and economies harness their human, materials and management resources for optimal productivity through financial agencies, hence stimulating economic growth. FS with economic growth within the developing economies, is a body of contemporary research, Nigeria inclusive. Studies have emerged that aim at evaluating FS on economic growth. For instance, in most developing nations like Nigeria, previous studies between FS and economic growth gave more attention to banking sectors and considered it an organized sector (Naomi \& Eftychia, 2018), while neglecting the potentials of stock market for efficient allocation and risk sharing in a liberalized financial market. This neglect according to Beck and Fuchs (2012) produce misleading results because the omission of a relevant variable from a system might invalidate causality inference. Although recent studies like that of (Naomi \& Eftychia, 2018; Ndako 2017; Nikolaidou, 2018; Mathenge 2016; Aziakpono, 2017; Rateiwa \& Aziakpono, 2015; and Gole \& Sun, 2013) deviated from such lopsided kind of study and evaluated the effect of financial institutions on economic growth, applying different methodology and variables in their studies.

Understanding financial structure and economic growth is extremely relevant to gain a better insight in its relationship (stock markets and banks) which is key to economic growth. Therefore, it would be important to determine how bank activity, bank size, bank efficiency, market activity, market size, and market efficiency affect the Nigerian economy and whether market-based or bank-based influence Nigerian economy or both. This research seeks to answer the questions; What is the relationship between bank credit to the private sector and economic growth? How do variations in liquid liabilities ratio, market capitalization ratio, turnover ratio, value of traded shares ratio and government expenditure affect economic growth?

Improved economic growth is the ultimate desire of every economy, including Nigeria. The role of the FS in the mobilization and efficient allocation of scarce resources to different sectors of the economy is sacrosanct to guarantee economic growth. This is because finance is aptly considered as the life wire of every economy. Thus, efforts have always been committed to 
Print ISSN: 2053-4086(Print), Online ISSN: 2053-4094(Online)

improving the financial structure of Nigeria's economy as well, given its relevance to economic growth.

However, the seemingly non-performance of the Nigerian economy in the wake of concerted efforts in evolving the financial structure of the Nigerian economy with the expectation of enhancing growth is worrisome. For instance, in Nigeria the Gross Domestic Product (GDP) growth rate in 1990 was 12.8 percent and 1.9 percent in 2018. Could it be that financial structure (comprises bank-based and market-based intermediation) in driving the much-needed growth were inadequate? This also brings to mind the debate in the theoretical sphere regarding the association amid the various mechanisms of the FS and economic growth. Existing theories '(bank-based (BB), market-based (MB), financial services (Fs) and law and finance)' suggest superiority over each other. The BB theorists argue that DMBs can finance growth more efficiently than MB in developing economies (Gerschenkron, 1962). Proponents of the MB theory are of the opinion that big, liquid and well-functioning markets improve growth better than banks (Levine, 2002, Beck \& Levine, 2002). Furthermore, the Fs-theory discourses that the cause of finance does not matter but instead the availability and provision of financial services (Arestis et al. 2004; Levine 2002b). Also, the law and finance theory posit that value of monetary facilities as determined by the authorised arrangement is what improves the effectual distribution of funds and economic growth (Laporta, Lopez-de-Silanes, Shleifer \& Vishny, 1997, 1998, 1999a, 1999b).

Empirical studies also showed lack of consistency in their findings in Nigeria. For instance, studies by Aigbovo and Uwubamwen (2016), Ibadin, Moni and Eikhomun (2014) discovered that FS is significant in ascertaining growth in Nigeria. Contrastingly, Maduka and Onwuka (2013), show that FS is not significant in explaining growth in Nigeria. More so the study by Ujunwa, Salami, Umar and Nwakoby (2012), showed that BB-theory and legal-based theory were helpful in encouraging economic growth, while the MB-theory and the Fs-theory were negative. It is against this backdrop the study considers examining the causal effect of financial structure on economic growth in Nigeria.

\section{LITERATURE REVIEW}

The catalytic role of financial structures all over the globe has long been recognized, hence they play an important role in a country's economic growth and development. In Nigeria, the flow of funds and other financial services are necessitated by the financial structure which include financial markets, financial institutions and rules within and outside the national economy (Nwumere, Onudugo \& Ibe, 2013). FS is regulated by CBN and other regulatory bodies like NDIC, SEC, NIC, FMBN and federal ministry of finance.

The connection between financial structure and economic growth can be studied on the foundation of contending theories of financial structure. These are: the bank-based theory, the market-based theory, the financial services theory and the legal based theory (Rateiwa \& Aziakpono, 2016; Ujunwa, Salami, Umar \& Nwakoby, 2012).

The BB-theory lays stress on the positive role of financial institutions in economic development, and also, show the inadequacies of MB-theories of financial structures. It claims that DMBs can finance growth more efficiently than markets in evolving economies, and, in 
state owned banks, market failures can be eliminated and resource allocation can be effected strategically. The BB-theory stresses the reputation of banks in recognising virtuous projects, assembling incomes, monitoring managers and handling risk, while emphasizing the shortages of MB-theory economies. According to the BB-theory led financial structures, especially in economies at an initial phase of economic development, are more effective at promoting growth than MB-theory led financial structures.

BB-theory led financial structures are in a much better position than MB-theory led structures to solve agency problems (Stiglitz, 1985). Information asymmetries are thus highlighted, more so in MB (market-based) than in BB (bank-based) financial systems (Boyd \& Prescott, 1986). DMBs can ease alterations stemming from asymmetric information through establishing longrun associations and onward monitoring of firms, which helps to contain moral hazard. Thus, bank-based provisions can harvest better improvement in resource allocation and corporate governance than 'market-based institutions' (Stiglitz, 1985; Bhide, 1993).

The MB-theory according to Boyd and Smith (1998), showed the benefits of well-functioning markets, thus stressing the deficiency of BB-theory led financial systems. The MB-theory stress that robustly liquid and well-functioning markets facilitate growth and profit, thus improving corporate governance and risk management facilitation (Levine, 2002, Beck \& Levine, 2002). Showing categorically that MB-theory led financial systems eliminate the inherent inadequacies related with banks and thus, proffering better enhanced economic development.

Recent World Bank (2016) study showed a case of MB-theory led financial systems in developing countries, prove to have asymmetric information. However, progress in technological facilities, accounting techniques and legal practices has facilitated improved tools of uncovering asymmetry information between users and providers of funds.

The MB-theory basically counter the BB-theory by concentrating on the problems generated by highly powered banks. First, in financing firms, banks get unpublicised information (inside information) which they use to extract rents from firms. More concretely, when making debt renegotiations, banks determine and control bargaining power of firm's anticipated future profits. Banks most often control large profit margins of negotiations thereby leaving the firms with lower incentives (Rajan, 1992). Secondly, high powered banks partner with managers thereby short-changing the position of competition which improves creation of new market opportunities and long run economic growth (Hellwig, 1998). This is evidenced in misrepresentation of firms' information by banks in Germany (Wenger \& Kaserer, 1998).

The Fs-theory (Merton \& Bodie, 1995; Levine, 1997), is consistent with the BB-theory and MB-theory. The Fs-theory provide that importance is hinged on financial services compared to form of delivery (World Bank, 2016). Thus, the financial services are key and not the source of finance. Hence, Fs-theory is anchored on the creation of an enabling environment for thriving of financial services for better functioning banks and markets rather than the specific type of financial structure in place. Therefore, efficient financial system reduces information asymmetries, risk and boosts savings mobilisation and leads to efficient allocation of capital (Peia \& Roszbach, 2014). This suggests that banks and financial markets works in cohesion to build a fairly competitive market economy. Governments therefore are to be concerned with creating better co-functioning of banks and markets in the economy (Levine 2002b). 
Different factors determine the development of one system as opposed to another which show the characteristics and circumstances in a country; this affect the financial system. Regardless, a balanced banking and market systems collective improve the development of the economy without any deficiency in any of the segments of the financial system.

Empirically, different position exists in the literature between financial structure and economic growth. For instance, Goldsmith (1969) provide comparison in the case of Germany and the UK for the period 1864-1914 and discovered that findings does not contribute to the debate since "one cannot well claim that a superiority in the German financial structure was responsible for, or even contributed to, a more rapid growth of the German economy as a whole compared to the British economy in the half-century before World War I, since there was no significant difference in the rate of growth of the two economies".

Levine (2002) supporting the position of Goldsmith's (1969) concludes that "financial structure does not matter much since the four countries under consideration have very similar long-run growth rates". The findings of this study thus do not support the provision of the BB-theory and MB-theory led financial system; they are, however, supportive of a better-developed financial services (system) which matters for economic growth.

Demirguc-Kunt \& Levine (1996), used ex post facto data for forty-four industrial and developing countries for the period 1986 to 1993 and concludes that countries with welldeveloped market-based institutions also have well-developed bank-based institutions; and countries with weak market-based institutions also have weak bank-based institutions, thereby supporting the view that the distinction between bank-based and market-based financial systems is of no consequence. The World Bank (2014) also provides a comprehensive instantaneous position which reached similar conclusions. Thus, "both the development of banking and market promote economic growth as each can complement the other".

Rateiwa and Aziakpono (2016) explore financial structure and economic performance in selected African countries. The study employed the Johansen cointegration and vector error correction modelling the period 1971-2013, in Egypt, Nigeria and South Africa. Firstly, cointegration test results showed that there exists a strong relationship between the financial structure of Egypt and South Africa, while showing a weak relationship in Nigeria. Secondly, the evidence also strongly suggests that the nature of the relationship between the financial structure of Egypt and South Africa and per capita GDP is positive. Financial structure is measured by the S-Size ratio and S-Activity ratio in Egypt and South Africa respectively while in Nigeria there is no evidence that financial structure influences per capita GDP. Lastly, coefficients of the error correction term for all three countries are low, suggesting inefficiencies in the financial system and possible rigidities within the economies.

Ujunwa, Salami, Umar and Nwakoby (2012) examine financial structure theories on economic growth in Nigeria. The study used time series data for the period of 1992 to 2008. The study using OLS regression estimation technique showed that the coefficients of BB-theory and LBtheory positively promoted economic growth, while the MB-theory and the Fs-theory negatively promote economic growth.

Aigbovo and Uwubamwen (2014) studies the short-run and long-run relationships between financial system development and economic growth in Nigeria. The findings of the study were 
that financial development (measured by banking system and stock market development) positively determine economic growth in Nigeria while also showing causality from finance to growth in the finance-growth nexus. Maduka and Onwuka (2013) investigated relationships between financial structure and economic growth. Using ADF and PP stationarity test, all the variables were stationary. The main results reveal that financial market structure has a negative and significant effect on economic growth based in Nigeria. This suggests a low level of development of the country's financial sector.

At individual country level, empirical study on the structure of the Nigerian financial system based on the researcher's knowledge is conclusively insufficient, yet the Nigerian financial structure is developing both in size, shapes and complexity. Therefore, it is apt to fill this gap in the study to determine the effect of financial structure on economic growth in Nigeria.

\section{RESEARCH METHODOLOGY}

This study adapts the model by Beck, Demir-guc-Kunt, Levine, and Maksimovic, 2001, Growth $_{i}=\grave{a} X_{i}+\beta F D_{i}+\gamma F S_{i}+\varepsilon_{i}$. However, to accommodate the researcher's variables structure, some modifications were made as follows;

$Y_{i t}=\alpha X_{i t}+\beta F S_{i t}+\varepsilon_{i t}$

Where $Y$ is real gross domestic product, a proxy for economic growth, $F S$ is the financial structure indicators, $X$ is control variable for economic growth and $\varepsilon$ is the error term. By decomposing financial structure into; bank credit to the private sector, liquid liabilities ratio, market capitalization, turnover ratio, value of traded shares and the control variable government expenditure, the stochastic form of the model is specified as;

$R G D P=\alpha_{0}+\alpha_{1} B C r+\alpha_{2} L L+\alpha_{3} M C+\alpha_{4} T R+\alpha_{5} T S+G E_{6}+\varepsilon_{1}$

Where: RGDP is real gross domestic product; $B C r$ is bank credit to the private sector ratio; $L L$ is liquidity liabilities ratio; $M C$ is market capitalization ratio; $T R$ is turnover ratio; $T S$ is Value traded shares ratio; $G E$ is government expenditure; $\alpha_{0}$ is the constant or the intercept term; $\alpha_{1}-\alpha_{6}$ are the parameter estimates. The data for this study is sourced from the world Bank Data Atlas on the following indicators or variables: economic growth; bank credit; liquid liabilities; market capitalization; turnover ratio; traded shares and the control variable, government expenditure. The data is essentially secondary and is measured on annual basis, from 1990 to 2018 . 
European Journal of Accounting, Auditing and Finance Research

Vol.8, No.3, pp.59-68, March 2020

Published by ECRTD-UK

Print ISSN: 2053-4086(Print), Online ISSN: 2053-4094(Online)

\section{RESULTS AND DISCUSSIONS}

The study examined the stationarity of the study by looking at the Augmented Dickey Fuller Unit root test of the study.

Table 1: Unit Root Tests for Nigeria

\begin{tabular}{|c|c|c|c|c|c|}
\hline Variables & $\begin{array}{l}\text { ADF } \\
\text { Statistics }\end{array}$ & Test & Critical Values @5\% & P-value & $\begin{array}{ll}\text { Order } & \text { of } \\
\text { Integration }\end{array}$ \\
\hline $\mathbf{D}(\mathbf{B C})$ & -3.520141 & & -2.976263 & 0.0152 & $\mathrm{I}(1)$ \\
\hline D(GDP) & -5.515195 & & -2.981038 & 0.0001 & $\mathrm{I}(2)$ \\
\hline $\mathbf{D}(\mathbf{G E})$ & -4.129503 & & -2.976263 & 0.0036 & $\mathrm{I}(1)$ \\
\hline D(LLR) & -4.759772 & & -2.976263 & 0.0008 & $\mathrm{I}(1)$ \\
\hline D(MC) & -5.786995 & & -2.976263 & 0.0001 & $\mathrm{I}(1)$ \\
\hline $\mathbf{D}(\mathbf{T R})$ & -5.361473 & & -2.976263 & 0.0002 & $\mathrm{I}(1)$ \\
\hline D(VTS) & -4.805137 & & -2.976263 & 0.0007 & $\mathrm{I}(1)$ \\
\hline
\end{tabular}

Source: Computation by researcher using E-view 10.0

The table 1 display the tests for stationarity properties of the series following the Augmented Dickey Fuller (ADF) statistics. All the variables were found to be stationery at order one (1) except GDP which was stationary at order 2. At both first and second difference as reported, the ADF Statistics for all the respective variables were all negative as well as the critical values significant at 5\% significance level. The reported $P$ values were all less than 0.05 chosen level of significance for which cause, the Null Hypothesis of the presence of unit root in all the variables is convincingly rejected.

\section{Tests for Co-integration}

Co-integration is used to model long-run equilibrium relationship (Brooks, 2014) and this is further supported by Woolbridge (2006). These thus necessitate co-integration method to test for the existence of long-run equilibrium relationship before we can proceed with the granger causality study.

Table 2: Co-integration Test Result @ 5\% level (Trace and Max-Eigen Statistics)

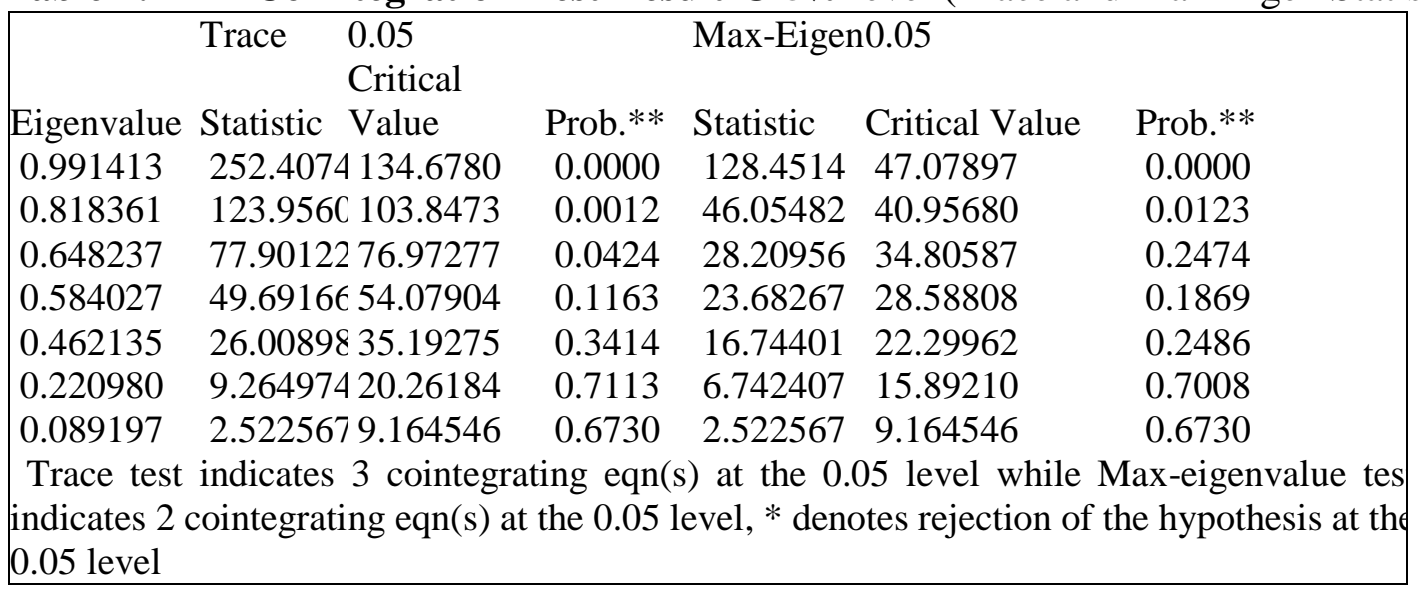

Source: Computation by researcher using E-view 10.0

The co-integration result in table 2 of the trace and maximum eigen-value tests shows the existence of five (5) co-integrating vectors with three (3) for trace statistics and two (2) for 
maximum eigen statistics (p-value of 0.0000, 0.0012 and 0.0424 for trace test and 0.0000 and 0.0123 for maximum eigen-value) between GDP, BC, GE, LLR, MC, TR and VTS at the 5\% level of significance. This thus confirms the absence of long-run equilibrium (cointegrating) effect of BCPS, GE, LLR, MC, TR and VTS on GDP.

\section{Test of Hypothesis}

$\mathrm{H}_{01} \quad$ There is no causal effect of financial structure on economic growth of selected SubSaharan African countries (Nigeria)?

$\mathrm{H}_{1} \quad$ There is causal effect of financial structure on economic growth of selected Sub-Saharan African countries (Nigeria)?

\section{Table 3: Pairwise Granger Causality Test for the Model}

\begin{tabular}{|lcccc|}
\hline Lags: 2 & Obs & F-StatisticProb. \\
Null Hypothesis: & 27 & 0.43661 & 0.6517 \\
BCPS does not Granger Cause GDP & & 3.75825 & 0.0394 \\
GDP does not Granger Cause BCPS & & 0.58670 & 0.5646 \\
GE does not Granger Cause GDP & 27 & 2.90051 & 0.0762 \\
GDP does not Granger Cause GE & & & 0.76767 & 0.4761 \\
LLR does not Granger Cause GDP & 27 & 2.09544 & 0.1469 \\
GDP does not Granger Cause LRR & & & 0.49002 & 0.6191 \\
MC does not Granger Cause GDP & 27 & 2.05497 & 0.1520 \\
GDP does not Granger Cause MC & & 1.02269 & 0.3761 \\
TR does not Granger Cause GDP & 27 & 0.71486 & 0.5003 \\
GDP does not Granger Cause TR & & & 0.16525 & 0.8487 \\
VTS does not Granger Cause GDP & 27 & & 1.31739 & 0.2881 \\
GDP does not Granger Cause VTS & & & \\
\hline
\end{tabular}

Source: Computation by author using E-view 10.0

The granger causality results showed a uni-directional causality effect from GDP to BC (with p-value of 0.0394) without a feedback effect from BC to GDP (since all the p-value 0.6517 is more than the 5\% chosen level of significance). However, the other financial structure variables in LLR, MC, TR and VTS were unable to granger cause a significant change in GDP with pvalues of $0.4761,0.6191,0.3761$ and 0.8487 with a corresponding lack of granger effect of GDP to LLR, MC, TR and VTS with p-value of 0.1469, 0.1520, 0.5003 and 0.2881 respectively. Hence, there are no causal effect from LLR, MC, TR and VTS to GDP in Nigeria.

This result is consistent with the findings of Naomi and Eftychia (2018), Guei (2018), Nikolaidou (2018), Luintel, Khan and Arestis (2016), Maduka and Onwuka (2013), Ayadi, Arbak, Ben-Naceur and De Groen (2013) and Levine (2002) who found non-causal effect of financial structure on economic growth. This result contradicts the position of our theory, the bank-based theory and market-based theory in financial structure and our apriori expectations of a positive significant effect. The result showed that none of the financial structure components was able to granger cause an effective change on economic growth (GDP) in Nigeria. 
Decision: Based on the general output, we accept the null hypothesis for BC, LLR, MC, TR and VTS (financial structure) that there exists no causal effect of financial structure on Nigerian economic growth.

\section{CONCLUSION AND RECOMMENDATION}

The study revealed that financial structure variables in BC, MC, LLR, TR and VTS does not granger cause a significant effective change on economic growth of Nigeria. From the analysis in 4.0, the results proved that financial structure have no long run relationship with economic growth in gross domestic product (GDP) and the financial structure was grossly unable to granger cause a significant effective change on economic growth (GDP) in Nigeria. In conclusion, based on the outcome of our study, the study affirm that financial structure has no significant effect on economic growth of the selected contemporary African economies (Nigeria). Hence, the study concludes that financial structure of the contemporary African economy in Nigeria should strengthen availability of money supply to key sector of the economy thereby improving economic growth by ensuring financial deepening within the economies and providing viable economic environment for financial enhancement to boost investment activities within the economies.

\section{References}

Aigbovo, O., \& Uwubamwen, A. E. (2016). Financial system development and economic

Growth: The Nigerian stock market and bank perspective. Journal of Business management 6(4), 155-172.

Arestisa, P., Luintelc, A. D., \& Luintel, K. B. (2004). Financial structure and economic growth: evidence from time series analyses, Applied financial economics, 20,479-492.

Boyd, J. H., \& Smith, B. D. (1998). The evolution of debt and equity markets in economic Development. Journal of Economics and Management, 12, 519-560.

Bhide, A. (1993). The hidden costs of stock market liquidity, Journal of financial economics, 34(1), 1-51.

Demirguc-Kunt, A., Feyen, E., \& Levine, R. (2011). Optimal financial structures and development: The evolving importance of banks and markets. Journal of Monetary economics, 21 (1), 41-53.

Demirguc-Kunt, A., \& Levine, R. (2001). Financial structures and economic growth: A crosscountry comparison of banks, markets, and development. MIT Press, Cambridge.

Gole, T., \& Sun, T. (2013). Financial structures and economic outcomes: An empirical Analysis. IMF Working Paper 4321

Gerschenkron, A. (1962). Economic backwardness in historical perspective. A book of essays, Cambridge: Harvard University Press.

Guei, K. M. A. (2018). Does financial structure matter for economic growth: An evidence from South Africa. Retrieved from https://mpra.ub.uni-muenchen.de/92823

Ibadin, A. L., Moni, M. O., \& Eikhomun, D. E. (2014). Development of financial system and economic growth: An empirical evidence from Nigeria, Journal of Business and Management, 30(6), 77-81.

Levine, R., (2002). Bank-based or market-based financial systems: Which Is Better? Journal of Financial Intermediation, 11(4), 398-428.

Levine, R., Loayza, N., \& Beck, T. (2000). Financial intermediation and growth: Causality and causes. Journal of monetary economics, 46(1), 31-77. 
4(4), 231-288

Mathenge, N. (2016). Financial structure and economic growth: evidence from sub-Saharan Africa. University of Cape Town, South Africa, and Kenya. Institute for Public Policy Research and Analysis, 7, 11-21.

Maduka, A. C., \& Onwuka, K.O. (2013). Financial market structure and economic growth: Evidence from Nigeria Data, Economic and Financial Review, 3(1), 75-98.

Ndako, U.B. (2017). Financial development, investment and economic growth: evidence from Nigeria. Journal of Reviews on Global Economics, 6, 33-41.

Naomi, M., \& Eftychia, N. (2018). Financial structure and economic growth: Evidence from Sub-Saharan Africa. Economic Research Southern Africa, Working Paper 732

Oima, A., \& Ojwang, C. (2013). Market-based and bank-based financial structure on

economic growth in some selected Ecowas countries, Journal of education and research, 41(2), 34-41

Rajan, R. G. (1992). Insiders and outsiders: The choice between informed and arm's length debt. Journal of finance 47, 1367-1400.

Rateiwa, R., \& Aziakpono, M. J. (2016). Financial structure and economic performance in selected African countries: Time series evidence, www.iosrjournals.org.https://pdfs.semanticscholar.org/6b2d/5732164110094549d3ee 99761d1d57aeb3f.pdf

Stiglitz, J. E. (1985). Credit markets and the control of capital, Journal of Money, Credit, and Banking, 17(1), 133-152.

Stiglitz, J. E. \& Weiss, A. (1983). Incentive effects of terminations: Applications to the credit and labor markets. American Economic Review 73(1), 912-927.

Ujuwa, A., Salami, O. P. Umar, A.H., \& Ifeoma, N. (2015). Financial structure andeconomic growth in Nigeria: Theory and evidence, journal of economics and finance

World Bank. (2016). World Development Indicators, Washington, DC: World Bank. 